\title{
MEMÓRIAS DA INFÂNCIA E DA ADOLESCÊNCIA NO ESPAÇO AFRICANO EM CADERNO DE MEMÓRIAS COLONIAIS, A ÁRVORE DAS PALAVRAS E O RETORNO 12
}

Cristina Arena Forli

Resumo: Tendo em vista a preponderância da utilização de memórias da infância e da adolescência na literatura contemporânea e a problematização da experiência do colonialismo português na África, este artigo tem como enfoque a análise dessas memórias em relação ao espaço do continente africano. Para tanto, optou-se por utilizar como corpus os seguintes romances: Caderno de memórias coloniais (2009), de Isabela Figueiredo, A árvore das palavras (1997), de Teolinda Gersão, e $O$ retorno (2012), de Dulce Maria Cardoso. Essas narrativas enfatizam o processo de formação desses sujeitos, que ocorre em concomitância a um momento histórico extremamente violento como é o colonialismo. Compreende-se essas memórias como subterrâneas (POLLAK, 1989) devido ao fato de assumirem a via da contramão do discurso histórico oficial. Dessa forma, o despertar para si e para o mundo acontece pelos olhos de quem vê com estranhamento muitas das ações tidas como naturais por adultos devido ao fato de estarem menos condicionados a um sistema disciplinar (FOUCAULT, 2004). Compõem o aporte teórico deste estudo autores como Maurice Halbwachs, Michael Pollak, Michel Foucault, entre outros.

Palavras-chave: Memórias da infância e da adolescência. Literatura contemporânea em língua portuguesa. Espaço africano.

Abstract: Considering the preponderance of the use of childhood and adolescence memories in contemporary literature and the problematization of the experience of Portuguese colonialism in Africa, this article focuses on the analysis of these memories in relation to the space of the African continent. For this purpose, the novels were

1 Este artigo é parte da reflexão que desenvolvo em minha tese de doutorado, em andamento, no Programa de Pós-Graduação em Letras da Universidade Federal do Rio Grande do Sul, sob orientação da Profa. Dra. Jane Fraga Tutikian.

2 Título em língua estrangeira: "Memories of childhood and adolescence in the african space in Caderno de memórias coloniais, a árvore das palavras and O retorno". 
used as corpus are: Caderno de memórias coloniais (2009), by Isabela Figueiredo, A árvore das palavras (1997), by Teolinda Gersão, and $O$ retorno (2012), by Dulce Maria Cardoso. These narratives emphasize the process of forming these subjects, which occurs concurrently with an extremely violent historical moment such as colonialism. These memories are understood as underground (POLLAK, 1989) due to the fact that they take the opposite route from the official historical discourse. Therefore, the awakening for themselves and for the world happens through the eyes of those who see with strangeness many actions taken as natural by adults because they are less conditioned to a disciplinary system (FOUCAULT, 2004). The theoretical contribution of this study is composed by authors such as Maurice Halbwachs, Michael Pollak, Michel Foucault, among others.

Keywords: Memories of childhood and adolescence. Contemporary literature in Portuguese Language. African space.

O crescente número de estudos sobre a memória e o grande interesse da literatura por abordá-la apenas certificam sua importância na contemporaneidade. Voltar o olhar para o passado permite que, a partir do presente, seja possível trazer à tona o que há de incompletude, hesitação, repetição nas narrativas, de modo a permitir uma visão mais crítica do que constitui esse presente. A palavra que evoca a lembrança tem o poder de não deixar esquecer aquilo que incomoda, evidenciando o caráter dissonante que pode exercer. Por meio dela, é possível dizer o que encontrou dificuldade para ser dito ou o que ainda não pôde ser dito.

A literatura expressa importante papel nesse sentido, pois possibilita a emergência de narrativas da memória, seja 
no âmbito individual, seja no âmbito coletivo. Se a memória é uma instância legitimadora de existências, o texto literário permite que a legitimação dessas existências se consolide pela palavra. Por meio do texto literário, é possível a inscrição de narrativas que confrontem o discurso histórico oficial e não deixem esquecer perspectivas perturbadoras, como tem ocorrido no caso das literaturas africanas e portuguesa.

O colonialismo português, em sua extensa duração, é visto como um processo histórico que teve seu fim no século XX, com a Revolução dos Cravos no ano de 1974 e com as independências dos países africanos, ocorridas em sua maioria no ano de 1975. No entanto, há ainda um silenciamento, no que diz respeito à discussão pública, sobre a forma como decorreu o colonialismo português ao longo da história e sobre a sua influência na contemporaneidade. Nesse sentido, parece haver uma preocupação por parte dos escritores do século XXI em problematizar a experiência do passado colonial no espaço africano e português, uma vez que essas sociedades estão intimamente imbricadas.

Para tanto, tem sido utilizada frequentemente a memória de personagens crianças com a finalidade de evidenciar uma perspectiva outra sobre o colonialismo, como destacado pela pesquisadora Margarida Calafate Ribeiro (2012), bem como 
a memória de personagens adolescentes. É por meio da curta trajetória de vida desses sujeitos, em um momento de mudanças tão significativas em seus corpos, de constituição de compreensões sobre o mundo e sobre si mesmos, que se tem uma visão menos automatizada do mundo, uma vez que, se a criança é mais individualizada que um adulto em um sistema disciplinar, como afirma Michel Foucault (2004), estaria então menos suscetível à automatização do olhar e das formas de viver.

Neste trabalho, são analisadas lembranças de infâncias e adolescências nas antigas colônias portuguesas na África a partir das narrativas Caderno de memórias coloniais (2009), de Isabela Figueiredo, A árvore das palavras (1997), de Teolinda Gersão, e O retorno (2014), de Dulce Maria Cardoso. Em busca de sentidos para si, os narradores desses romances apegam-se à memória para tentar compreender essas fases de suas vidas em um passado em comum que deixou marcas inapagáveis: os últimos anos do colonialismo português na África.

Gita, narradora de $A$ árvore das palavras, Rui, narrador de $O$ retorno, e a narradora de Caderno de memórias coloniais, assumidamente autobiográfica e ficcional, recorrem às suas memórias como necessidade de afirmação 
de suas individualidades. Essas subjetividades reconstruídas narrativamente se inscrevem, com a força da palavra, historicamente, mesmo que sua existência ou suas narrativas tenham sido negadas. Suas lembranças são individuais, mas também fazem parte de uma coletividade, pois, como defende o sociólogo francês Maurice Halbwachs (2003), não é possível desvincular o indivíduo da sociedade de que faz parte. Grupos sociais de que se faz parte, espaço e tempo vividos ou com os quais se estabelece identificação são determinantes para a memória. Daí o motivo de afirmar que a memória não se encerra em si mesma nem é solitária.

Compreendendo a lembrança como uma reconstrução do passado que se apoia no presente, Halbwachs ressalta que essa reconstrução envolve outras reconstruções, realizadas em diferentes momentos da vida, o que causa modificação na imagem lembrada. Nesse sentido, a lembrança sempre sofrerá alterações. Não é possível, portanto, pensá-la como uma imagem estanque a que se tem acesso ou não. Michael Pollak (1989, 1992), em continuidade aos estudos do sociólogo, enfatiza o caráter conflitivo da memória. Para Pollak (1989), é com base em preocupações e interesses do presente que se estrutura a memória, seja individual, seja coletivamente. Desse modo, a memória entra no campo de 
disputa social, gerando conflitos políticos e éticos a fim de determinar o que deve ser lembrado e esquecido.

Pollak (1989) destaca a batalha pela memória que vinha se assistindo na história. Batalha essa que não cessa de acontecer e que em tempos de tecnologias da informação e comunicação tem assumido outros formatos. Com base no material histórico, é realizado um trabalho de enquadramento da memória. Esse material é reunido e interpretado a partir de diferentes referências a ele associadas e de enfrentamentos entre o presente e o futuro, tendo em vista a manutenção de fronteiras sociais, mas também a sua modificação. $O$ trabalho de enquadramento da memória exige a escolha por "testemunhas autorizadas" (POLLAK, 1989, p. 11), isto é, testemunhas que vão sustentar a memória que se quer manter.

São os períodos de crise ou de guerra que favorecem a emergência de memórias subterrâneas (POLLAK, 1989, p. 5), as memórias conflitantes em relação à memória oficial. Trata-se das memórias que reabilitam os discursos periféricos, que resistem ao esquecimento e rompem com o silêncio imposto. As memórias dos narradores em questão são compreendidas como memórias subterrâneas, pois possibilitam a problematização de narrativas de coesão, 
como o discurso histórico oficial, retirando do subsolo suas experiências no continente africano, espaço da infância, onde aprendem a existir no mundo, e de onde precisam sair.

Em Caderno de memórias coloniais, a determinação do espaço da infância é realizada já no início do romance, com a fotografia de abertura da ainda Lourenço Marques, atual Maputo, cuja legenda, além do nome da cidade, contém as informações sobre o bairro, Alto Maé, e o ano, 1960. É também com uma fotografia da cidade que a narrativa se encerra, em que se encontra, da mesma forma, uma legenda com o seu nome e o ano de 1960.

O bairro mencionado na primeira fotografia é um dos mais antigos da cidade, situado em uma região central. A localização temporal, indicada pelo ano nas duas legendas, é de um momento em que ainda perdura o colonialismo, sob a ditadura de Salazar durante o Estado Novo, no ano de 1960. A associação do registro fotográfico ao título do livro dá a impressão ao leitor de que está diante de um álbum de família. É como se a narradora colocasse o leitor diante desse álbum familiar para orientá-lo sobre o que discorrerá ao decorrer das páginas.

Tal como muitas famílias incentivadas a sair da metrópole, que passava por dificuldades econômicas, o pai da narradora 
parte para Moçambique em busca de melhores condições de vida, mesmo que essa melhoria custasse a exploração dos sujeitos negros. Fruto de um casamento realizado por procuração, como muitos na época, a narradora nunca esteve em Portugal. Seu conhecimento sobre a metrópole está restrito ao discurso de sua família. Lourenço Marques é a referência de seu espaço da infância. Na cidade, à medida que ocorre uma apropriação do espaço, há também o despertar de uma conscientização social.

As lembranças sobre a cidade evidenciam uma divisão na organização do espaço que segue uma lógica de hierarquia social. Os corpos são classificados conforme suas características e é de acordo com essa classificação que devem ocupar os espaços da cidade. Em oposição à urbanização gradual da cidade dita de cimento, habitada preponderantemente por brancos, existia o Caniço, bem distante do centro urbano.

O caniço era para os lados de Xipamanine, ou do aeroporto, ou longe, longe. $\mathrm{O}$ caniço era como o labirinto do Minotauro, e o meu pai era o Minotauro que aí entrava e saía, quando Ihe apetecesse, para exercer a sua justiça. O caniço talhava-se de caminhos estreitos, recortados por entradas para aglomerados de palhotas, onde se juntavam mulheres falando, crianças chorando ou brincando, cães sarnosos dormindo, cabritos remoendo 
capim, pilões pilando milho, vozes altas, latas de comida fumegando sobre o carvão; a vida. O caniço era construído de cana velha, já cinzenta, ou nova, cor de café com leite clarinho. (FIGUEIREDO, 2015, s. p.)

No excerto, a própria narradora explicita a distância do Caniço em relação ao centro urbano. A repetição do advérbio definidor da distância no primeiro período remete às definições espaciais pensadas na infância. A exploração do espaço do bairro se dá junto da figura paterna, que vai ao local coagir e humilhar um de seus empregados em frente à família por ter faltado ao trabalho. A equiparação entre o bairro e o labirinto do Minotauro diz muito sobre a visão infantil e a percepção da organização do local: a figura do pai, cuja imagem é associada a uma espécie de fera, é a única capaz de explorar o espaço, visto como caótico na perspectiva infantil, por isso, definido como labirinto pela mulher que escreve.

Devido ao incentivo para a ida para as colônias durante o salazarismo, há um intenso crescimento da cidade a partir da década de 1950. Com isso, há a imposição do deslocamento das pessoas pobres para áreas menos privilegiadas, gerando cisões no espaço. Além da cisão gerada pelo Caniço, ainda a cidade dividia-se em alta e baixa, sendo a primeira o lugar onde ficavam as instituições 
de administração, religiosas e as moradias de pessoas mais favorecidas economicamente, em geral colonos brancos, e a última o local onde eram realizadas as negociações, onde se localizava o centro comercial e também onde residiam pessoas com menor poder aquisitivo (MELO, 2013).

Ao relembrar o espaço africano, é inevitável que as lembranças façam emergir em algum grau as posições dos sujeitos que ocupam esse espaço, as quais são bem demarcadas.

Em Moçambique era fácil um branco sentir prazer de viver. Quase todos éramos patrões, e os que não eram, ambicionavam sê-lo. Para esse fim, havia sempre muitos pretos, todos à partida preguiçosos, burros e incapazes a pedir trabalho, a fazer o que lhes ordenássemos sem levantar os olhos. (FIGUEIREDO, 2015, s. p.)

Analisando o passado em sua vida adulta e reproduzindo o discurso que ouvia, a narradora lembra-se do local onde nascera e de sua lógica de funcionamento para sujeitos brancos e negros, de modo a destacar a facilidade para os primeiros, que apenas foi possível pela violência para com os segundos. Violência essa já explícita na reprodução do discurso de cunho depreciativo, que determina esses sujeitos como "preguiçosos, burros e incapazes", submissos, e que reduz as suas existências à servidão ao branco, a fim de que exerça a sua função de patrão e civilizador. 
As análises sobre o vivido são uma constante ao longo do texto e só reforçam a importância, para a narradora, da leitura, uma vez que a atitude reflexiva é permitida pela possibilidade de ler o mundo, ler novamente as lembranças sobre um passado constantemente presente. Daí o motivo de a narradora afirmar que seus livros mostravam que no lugar onde vivia a redenção não era possível. "Que aquele paraíso de interminável pôr-do-sol salmão e odor a caril e terra vermelha era um enorme campo de concentração de negros sem identidade, sem a propriedade do seu corpo, logo, sem existência" (FIGUEIREDO, 2015, s.p.). A leitura foi fundamental para que, na infância, a consciência sobre o mundo tivesse seu desenvolvimento.

O contraste entre "paraíso" e "campo de concentração" acentua duas perspectivas distintas tanto em relação à beleza que a geografia de Moçambique apresenta e ao que a terra representa em termos sociais aos sujeitos brancos que se mudam em busca de melhores condições de vida, quanto em relação às condições desumanas em que viviam os sujeitos negros, destituídos inclusive da posse de seus corpos, o que acarreta a perda existencial, conforme as palavras da narradora. Nesse sentido, as lembranças sobre esse mesmo espaço colonial da infância possibilitam análises 
distintas, de acordo com as posições ocupadas pelos sujeitos e são reveladoras do funcionamento do sistema colonial para a drástica e injusta disparidade de realidades.

Não só as lembranças da narradora de Caderno de memórias coloniais tornam bem evidente a separação dos sujeitos no espaço africano da infância, mas também as de Gita, narradora de $A$ árvore das palavras. A estreiteza de sua relação com Lóia, empregada da família, desde a infância, possibilita uma aproximação da realidade dos sujeitos negros, uma vez que a personagem vivia no Caniço. Sobre a localização do bairro na cidade de Lourenço Marques, ainda criança, Gita pergunta a Lóia:

Mas "longe" onde é, quero saber - mais longe que o Chamanculo, a Avenida Angola, Munhuana, Xipamanine, Mafalala? Mais longe que a Estrada das Lagoas?

Ela repete: Sim. Longe. E suspira.

Dos negros não sabemos nada, diz Amélia. Nem podemos procurá-los porque não sabemos onde moram, não tem endereço, vivem em sítios vagos, palhotas iguais umas às outras, no meio de corredores de caniço. É agulha em palheiro, se se quiser achar alguém. (GERSÃO, 2004, p. 26)

As localizações citadas pela narradora são exemplos de regiões afastadas do centro, em geral bairros considerados suburbanos, e mencionadas, assim, como referência 
geográfica para traçar de forma estimada a distância do Caniço, a qual Lóia percorria diariamente para trabalhar. A fala da mãe de Gita, Amélia, sobre os sujeitos negros ecoa na memória de Gita, de modo que ao longo da narrativa diversas são as menções à afirmação de que não é possível saber nada sobre os negros, de que são traiçoeiros. Essas lembranças sobre os discursos da mãe evidenciam a discordância da narradora em relação a eles, desde criança, e a definição, por isso, de posicionamentos bem opostos, apesar do vínculo sanguíneo.

A descrição sobre o bairro desconsidera a segregação imposta espacialmente, bem como o descaso das instituições coloniais para com os subúrbios, uma vez que, conforme Zamparoni (1998), as ruas, em sua maioria, não tinham nomes nessas regiões nem passavam por outras intervenções para suprir necessidades básicas dos habitantes. Sendo assim, da mesma forma que os sujeitos pareciam indistinguíveis ao olhar do colono, suas habitações também assim Ihe pareciam, como bem destaca Zamparoni (1998) sobre a cidade de Lourenço Marques, semelhantemente à representação do romance de Gersão.

No terceiro capítulo de $A$ árvore das palavras, em que ocorre a retomada de lembranças predominantemente 
da adolescência, Gita traz à tona uma lembrança bastante detalhada e imagética sobre as habitações:

Lóia estava ligada ao mundo quotidiano dos negros, aos bairros pobres que por toda a parte nos cercavam - casas baixas, pintadas, feitas de pedações de materiais avulsos, que pareciam desenhos de crianças da escola ou cenários abandonados, desbotando ao sol: Uma porta e duas janelas, uma de cada lado, mais abaixo uma faixa pintada de azul forte, amarelo ou rosa. Em cima, sem forro, um telhado mal assente, às vezes também debruado a tinta. E na entrada em geral um degrau ou dois, para encher o espaço que faltava até à rua.

Através das portas abertas viam-se, dentro das casas, pedaços desconexos de coisa nenhuma, uma mesa, uma cama no meio de um quarto, um armário partido, uma cadeira esventrada, algures ouvia-se um rádio tocando alto, barulho de vozes, choros de criança ou de mulher. (GERSÃO, 2004, p. 153)

A composição das habitações recupera a carência, também tratada por Zamparoni (1998), de recursos materiais. Uma vez que as palhotas de caniço e barro foram proibidas na cidade, sendo substituídas por casas de alvenaria ou madeira com telhado de zinco, surge a necessidade de comprar materiais e pagar por um serviço, já que as pessoas não conheciam esse tipo de construção. Essa nova forma de construção das casas está atrelada 
aos diversos projetos coloniais de urbanização que tinham como objetivo a modernização da cidade.

A substituição das palhotas redondas de materiais oriundos da natureza por casas retangulares de alvenaria ou madeira com telhados de zinco ainda abarca a dimensão simbólica de abandonar uma forma considerada primitiva (a circular) e assumir uma considerada evoluída (a retangular) (ZAMPARONI, 1998). Na impossibilidade de adquirir os materiais, então, para as construções, eram aproveitados materiais possivelmente descartados por outros, o que dá a impressão em Gita de que são "cenários abandonados", porque the parecem incompletos e decadentes devido à falta de recursos.

De acordo com a memória de Gita, assim, os espaços reservados aos negros, além de promoverem a exclusão desses sujeitos, refletem o completo descaso por parte do colonizador com o bem-estar alheio, bem como uma forma de aniquilação de suas subjetividades. Ainda são importantes indicadores de uma visão do outro. Um outro tão indigno a ponto de não ser considerado cidadão. Albert Memmi (2007) critica o fato de o colonizado não ter direito a nenhum dos atributos da nacionalidade. Não há lugar para o sujeito negro na cidade, assim como não 
há a possibilidade de usufruir de direitos como qualquer cidadão, o que ocasiona uma fratura em sua identidade.

Como bem destaca Boaventura de Sousa Santos (2019), sustentou-se tão eficazmente a ideia de que o colonialismo acabou após as lutas independentistas do século XX que é quase absurdo pensar que ele não chegou ao fim. No entanto, como elucidado por Grada Kilomba (2019, p. 61), ainda hoje "as relações de poder desiguais de 'raça' são então rearticuladas nas relações de poder desiguais entre os espaços". Assim, a memória sobre o espaço onde viveram na infância parece despertar nas narradoras a consciência para a diferença social pela percepção das distâncias entre os bairros, da formação excludente da cidade, da falta de recursos básicos à vida dos sujeitos negros.

É nesse espaço da infância em que percebe a segregação social que Gita estabelece identificação com Lóia a ponto de definir locais diferentes para os integrantes da família. Ela, o pai e Lóia pertenceriam à Casa Preta e ao quintal, onde há liberdade e vida, como representação do espaço africano. Já a mãe pertenceria à Casa Branca, local de assepsia, desconfiança e medo, em representação à Europa. Há, nesse sentido, um sentimento de identificação com o espaço da infância. Suas lembranças sobre a 
infância trazem a marca do afeto que destina à Lóia, ao pai e a Moçambique.

Em $O$ retorno, tendo como presente o dia da partida de Angola para Portugal, numa tentativa desesperada de agarrar um mundo familiar, o adolescente Rui afirma: "Insistimos em pormenores insignificantes porque começámos a esquecer-nos. E ainda nem saímos de casa" (CARDOSO, 2012, p. 8). Esse apego ao que ele denomina como "pormenores" se faz fundamental para fornecer algum suporte e segurança. São retomadas, na narrativa, diversas lembranças recentes que envolvem o cotidiano familiar em Luanda e posteriormente em Portugal.

Nas palavras de Halbwachs (2003, p. 158): “A estabilidade da habitação e sua aparência interior não deixam de impor ao grupo a imagem pacificante de sua continuidade". É a sensação de imobilidade proporcionada por esse espaço então que gera um sentimento de estabilidade, que é reconfortante, uma vez que o espaço conhecido faz recordar formas de ser comuns a muitas pessoas. Desse modo, a memória acerca da casa da família, em Angola, evidencia o quanto esse espaço se configura um lugar de afirmação no mundo, de constituição de identidade, de reconhecimento, de identificação, de construção de uma memória comum. 
No entanto, habitar a casa não é mais seguro devido à guerra, que impõe o deslocamento da família e, portanto, significativa perda de subjetividade, de um lugar social e de perspectiva futura.

Para consolar-se, o narrador procura vantagens na ida para a metrópole, as raparigas e as cerejas. A supervalorização de Rui aos elementos portugueses encontra sustentação no discurso colonial, ancorado por uma memória oficial, que circula no presente da narrativa e que tem na mãe e no pai seus propagadores, ainda mais em uma fase da vida tão suscetível à influência familiar. O narrador reflete sobre os efeitos de Angola para a doença da mãe e o que dizem ela e seu pai sobre a ida para a África:

A culpada de a mãe ser assim é esta terra. Sempre houve duas terras para a mãe, esta que a adoeceu e a metrópole, onde tudo é diferente e onde a mãe também era diferente. O pai nunca fala da metrópole, a mãe tem duas terras mas o pai não. Um homem pertence ao sítio que lhe dá de comer a não ser que tenha um coração ingrato, era assim que o pai respondia quando the perguntavam se tinha saudades da metrópole. (CARDOSO, 2012, p. 11)

Rui apenas repete a afirmação de sua mãe, que culpa o local onde vivia por sua condição mental. Para o pai, são demônios que entram pelo corpo da mulher, e, para ela, o 
local onde esses demônios existem é Angola, a terra que a adoece. Essas afirmações sobre a doença da mãe e a culpa da terra são repetidas diversas vezes ao longo da narrativa. A repetição do narrador apenas confirma a projeção ou transferência (POLLAK, 1992) da memória familiar acerca do espaço: um espaço caracterizado de forma estereotipada, uma África mítica, misteriosa, repleta de demônios, que está intimamente atrelada à visão preconceituosa sobre as religiões africanas.

Essa visão do espaço gera o sentimento de pertença ao grupo familiar e, de uma forma mais ampla, à identidade colonial portuguesa, pautada na superioridade do sujeito português e na inferioridade do sujeito africano. Tem como base narrativas, perpetuadas por uma memória oficial, de diminuição do sujeito negro, visto como o outro, e de sua cultura, que são sustentadas por uma perspectiva de espaço como um sistema fechado, uma simples superfície, que precisa ser dividido conforme uma hierarquização imposta pela "raça" e cuja divisão corresponde a uma sequência temporal, como ensina Doreen Massey (2008). Essa dinâmica implica o estabelecimento de uma concepção de desenvolvimento em função do tempo que não leva em consideração as diferenças nas trajetórias, porque as reduz a uma só. 
Ao mesmo tempo, é desse espaço onde viveu infância e parte da adolescência, tão desprezado pela mãe antes da partida para Portugal, que o adolescente sente saudade. Juntamente a essa partida, que precisa ocorrer sem a figura basilar da família, Mário, pai do narrador, que é preso antes da partida, há a imposição da identidade como retornado. Retomar as narrativas que caracterizam a família, os vizinhos, os amigos, o espaço e as transformações que este foi sofrendo, bem como as posições dos sujeitos em relação a ele, é uma forma de agarrar-se à memória que Ihe resta, ao que de conhecido ainda lhe resta. É o choro da mãe que faz Rui regressar à consciência da ruptura dessa continuidade e fazer a seguinte reflexão no presente:

[...] a nossa última manhã. Tão silenciosa apesar dos tiros. Nem os tiros conseguem desfazer o silêncio da nossa partida, amanhã já não estamos aqui. Ainda que gostemos de nos enganar dizendo que voltamos aqui. Angola acabou. A nossa Angola acabou. (CARDOSO, 2012, p. 14)

O processo de descolonização e a consequente imposição da ida para Portugal geram uma cisão entre grupo e espaço. O narrador tem consciência da impossibilidade de voltar à Angola que ele e sua família conheceram. Por isso a tentativa de gravar o máximo possível do que lhe é familiar, a fim de ter 
referências que sustentem as lembranças de um momento crucial na sua constituição enquanto sujeito. Esse lugar no mundo ao qual não é possível voltar é também a infância e a adolescência, a condição de dependência dos pais e de isenção de responsabilidades delegadas aos adultos. A metrópole que decepciona desde a chegada e que Ihe foi imposta, uma vez que a família não escolheu partir, pode ser compreendida como sinônimo da vida adulta, que também se impõe com o envelhecimento.

Enquanto em Angola o narrador podia exercer seu papel de filho em cumplicidade com o pai, na metrópole, sem o pai e como único membro homem da família junto da mãe e da irmã, vê a necessidade de assumir o papel adulto e basilar que o pai exercia na família. Daí um dos motivos para a espera incessante pelo retorno de Mário. É Rui quem precisa falar firmemente, embora com muita dificuldade, as palavras que o pai dizia para a mãe quando de suas crises nervosas. É também ele que planeja como comprar os bilhetes para levar a mãe e a irmã para o Brasil, quando acredita que o pai morreu após a independência de Angola. A volta do pai simbolizaria, em alguma medida, o retorno do direito ao restante de sua adolescência, a restituição ao direito de ser filho apenas. No entanto, o pai que chega a 
Portugal não é o pai com quem viveu em Angola. É, sim, um pai marcado pela violência que a prisão impôs.

A conscientização gradual apresentada pela narradora de Caderno de memórias coloniais também é fundamental para a constituição de sua subjetividade e sua compreensão do espaço da infância. A comparação entre as condições de vida de crianças brancas e negras possibilita um incômodo inicial, pois a narradora não vê como naturais as diferentes posições atribuídas aos corpos conforme a cor da pele, como seria comum ocorrer com muitos dos adultos. $\mathrm{O}$ episódio a seguir é significativo para pensar essa questão.

Os pretos começavam a pedir trabalho às nossas portas desde crianças, rapazes e raparigas. Batiam ao portão, abríamos, e apareciam crianças esfarrapadas, descalças, ranhosas e esfomeadas de farinha dirigindo-nos as poucas palavras que conheciam, "trabalho, patrão". Crianças da minha idade ou mais novas. Abria a porta aos pedintes e ficava a olhá-los sem palavras. Não compreendia. Chamava a minha mãe, que rapidamente enxotava, "vai-te embora, aqui não há nada", e eu seguia para o meu quarto e continuava a ler Dickens ou o que quer que fosse. Não compreendia. (FIGUEIREDO, 2015, s.p.)

O encontro com as crianças negras à porta de casa fica marcado na memória da narradora, de modo que é possível 
recordar a forma como se apresentavam quando desse encontro. As ações de abrir a porta e olhar são como equivalentes a um processo de transição do simples olhar ao reparar. A não compreensão, mencionada pela narradora, é uma evidência da reflexão de adulta ao retomar essa lembrança. No entanto, há nitidamente um acometimento da narradora diante desse encontro, que a deixa sem palavras e em que ocorre uma espécie de espelhamento na construção da imagem das duas crianças com ênfase para a diferença.

Na reflexão a seguir, essa imagem espelhada é esclarecida.

Moçambique é essa imagem parada da menina ao sol, com as tranças louras impecavelmente penteada, perante a criança negra empoeirada, quase nua, esfomeada, num silêncio em que nenhum sabe o que dizer, mirando-se do mesmo lado e dos lados opostos da justiça, do bem e do mal, da sobrevivência. (FIGUEIREDO, 2015, s.p.)

As duas crianças são colocadas uma em frente à outra, por força de uma necessidade de análise da mulher que narra, com o sol a iluminar suas diferenças físicas tão marcadamente visíveis: uma branca, loira, com cabelos alinhados; a outra negra, com pó sobre seu corpo praticamente nu e com fome. A oposição entre essas 
crianças, cujos corpos evidenciam vidas tão distintas, realça a crueldade a que são submetidas, mesmo estando "do mesmo lado", como a narradora afirma, por serem simplesmente crianças. Desse modo, o acometimento que acontece à narradora ainda na infância também acontece ao leitor, que vê diante de si as duas crianças, uma branca e outra negra, uma com direito à infância, outra sem a garantia sequer ao alimento.

Além da conscientização sobre seu lugar no mundo, o narrar a si propicia a consciência da permanência do passado, da terra, da infância, do colonialismo e do pai. O trecho a seguir exemplifica bem essa questão:

[...] e neste instante em que tudo está perdido, em que já não há volta, em que entro por essa porta de vidro, após os beijos formais, um sentimento estranho que não consigo controlar, um vazio, um nunca mais vou voltar, uma coisa que se perde, um vazio, e esse amor tão escondido, tão evidente pelo meu pai, que me projeta para os seus braços, contra a minha vontade, como uma bala que o atravessa e o torna exangue, eu chorando a fio, não conseguindo largar o seu corpo, os seus braços enormes, o seu corpo enorme, as suas mãos enormes, a sua carne enorme, que beijo, que não quero largar.

$[\ldots]$

Já estou aqui, contudo, ainda estou lá. Todo o passado, presente e futuro ali se fundiram, naquela viagem, e eu só posso falar usando 
as palavras de fronteira, de transição, manchadas, duais que aí se formaram. (FIGUEIREDO, 2015, s.p., grifos nossos)

Destaca-se, no primeiro excerto, os verbos utilizados no presente, bem como os pronomes demonstrativos, que sugerem proximidade. Esses recursos possibilitam uma aproximação em direção ao passado e permitem pensar que lembrar esse momento da vida é como revivê-lo devido ao trauma gerado, a ruptura com a figura paterna em um momento ainda tão precoce. Por isso, é possível a consciência de que ainda se permanece no passado, ou seja, na infância e em Moçambique. Ainda é esse passado responsável por fazer a narradora utilizar as angustiantes palavras de fronteira, da impossibilidade de pertença aos locais em que viveu, Moçambique e Portugal, para inscrever e escrever a memória.

É essa ideia de permanência do passado na memória que permite a seguinte reflexão:

Criei o quarto-Império, para onde atirei aquilo de que não consigo libertar-me ainda, e, dentro dele, as caixas-Império. Venham buscar.

Uma pessoa precisa de tempo para conseguir atirar o passado borda fora.

Libertei-me de muito. Dei. Vendi ao desbarato. Reciclei. Neste momento, o mais vivo mono do Império que por aqui resta, acho que sou eu. (FIGUEIREDO, 2015, s.p.) 
É possível compreender o quarto-império tanto com o sentido de local, de acordo com suas palavras, para onde a narradora atira o que ainda não pode se libertar, quanto como número ordinal. O que é objeto de desejo de libertação é o passado colonial. O tempo é indicado como necessidade pela narradora para que seja possível livrar-se desse passado. Quase como entidade apaziguadora, é como se a sua passagem garantisse o ruir da lembrança.

No entanto, apesar de a narradora ter conseguido se libertar de muito, ainda não foi suficiente, pois o que resta do império está em si, inscrito em sua memória, em seu corpo, em sua forma de ver o mundo. Não é possível esquecer, pois esse passado constitui também a sua infância. E, como bem destaca Tomaz de Figueiredo na epígrafe de $A$ toca do lobo: "Nunca nos curamos de nossa infância". Essa fase da vida, compreendida como uma ferida, significativa metáfora para a memória, não pode ser sarada porque permanece latente em cada um.

Em $O$ retorno, o esquecimento é visto como uma ameaça inicialmente, pois é a memória que possibilita saber quem se é e tentar segurar algo da infância, do pai, de Angola. Sem referências espaciais é ainda mais importante fixá-la, já que não haverá, em Portugal, nem objetos que auxiliem nesse processo. 
O silêncio que permeia a ida para a metrópole, a falta de perspectiva para o futuro, o cessar das atividades cotidianas, a relação da mãe com as vizinhas em Luanda, a relação do pai com a metrópole e Angola, a manhã do dia da partida (tão semelhante às manhãs de domingo), a dinâmica e as diversas histórias familiares são apenas alguns exemplos sobre as inserções do passado recente na narração de Rui. A consciência sobre o fim de um tempo, sobre não poder voltar, não ter mais contato com os amigos e vizinhos horroriza o adolescente. Ao mesmo tempo, essas reflexões sobre o passado possibilitam que o leitor acompanhe seu processo de amadurecimento.

Acerca da expectativa positiva do pai na virada do ano 1974 para 1975, Rui se lembra:

Só que a banda nunca mais passou. Foi tudo tomando o seu lugar, cada um de nós no seu canto e em cada canto uma dor. Durante algum tempo o pai continuou a acreditar que 1975 ia ser o melhor ano das nossas vidas, vai correr tudo bem, vamos construir uma nação, pretos, mulatos, brancos, todos juntos vamos construir a nação mais rica do mundo, melhor até que a América, isto é uma terra abençoada onde tudo o que se semeia nasce, não há no mundo outra terra assim. (CARDOSO, 2012, p. 32-33)

Essa lembrança sobre a festa de fim de ano é um significativo registro de uma memória de frustração bem 
delimitada no tempo, permitida pelo desenvolvimento de uma criticidade. Tal como na canção "A banda" (1966), de Chico Buarque, como forma de amenizar a dor da gente sofrida, em Luanda, a banda deixa de passar depois da ilusão gerada pela festa. O que resta, depois que tudo volta ao seu lugar, é a dor dos que permanecem em Angola na esperança de que não precisassem abrir mão da vida que tinham no país.

Após a partida de Angola, Rui vive o presente em Portugal, mas está muito vinculado ao passado no país onde nascera, semelhantemente à narradora de Figueiredo. O tempo de espera faz a percepção sobre a duração dos dias se alongar, criando a sensação de que custam a passar, como afirma Rui, uma vez que as esperas se somam por dizerem respeito não só à chegada do pai, mas ao lugar no restaurante, ao lugar na sala de televisão e ao grande dia, o dia da partida do hotel. Em Portugal, ao vivenciar esse tempo de espera no hotel, o jovem vê no esquecimento uma necessidade para manter a vida no presente. É necessário, assim, esquecer a vida que se teve em Angola, a casa, os objetos, o jardim, os amigos, a vizinhança, para poder seguir em frente, conforme seu pensamento.

Se a narradora de Caderno de memórias coloniais vê no presente da narração o que há de mais vivo no império 
como a si mesma, a partir da avaliação proporcionada pela memória, Rui, ao lembrar-se da ida recente ao Instituto de Apoio ao Retorno de Nacionais (IARN), vê nos retornados, que na sala da instituição estavam, o que restava do império, em todo seu cansaço, fome, derrota e humilhação. Por representarem um passado sobre o qual ninguém quer saber, muito menos se responsabilizar, esses sujeitos, incluindo a família de Rui, sofrem as consequências de carregarem em si essa memória, por serem representações vivas dela.

$\mathrm{Na}$ contramão da tentativa de silenciamento, surgem memórias subterrâneas não só ficcionais, como as analisadas, mas também não ficcionais. Um exemplo destes últimos casos são as histórias reunidas por Catarina Gomes em Pai, tiveste medo?. Na obra, a jornalista registra doze histórias de filhos que conheceram a guerra colonial por meio da memória dos pais e criaram memórias próprias sobre o conflito.

Há, na casa desses filhos, vários objetos que auxiliam na retomada da memória sobre a África, na medida em que carregam consigo alguma história familiar. Entre essas histórias, muitas lembranças se assemelham à memória familiar dos narradores de Cardoso, Figueiredo e Gersão. Mais especificamente em "Cabeça de veado", André, um dos entrevistados, relata o seguinte: 
O pai nasceu em Tabuaço, mas foi para Angola com treze anos - guarda da infância na vila beirã recordações duras a plantar couves e a trabalhar nas vinhas -, a mãe é de Vila Nova de Gaia e foi com a família para a África aos nove anos.

Só regressaram os dois a Portugal quando se tornou impossível continuar em Angola. Foram os últimos da família a sair porque eram o que lá mais queriam ficar.

[...]

A caminho do aeroporto confirmaram, pelos corpos que foram vendo espalhados, que não podiam mais ficar. A guerra civil estava instalada. Puseram o máximo de vida que conseguiram num contentor. À chegada a Portugal chamaram-Ihe retornados. (GOMES, 2014, p. 110)

É impossível não pensar nos pais de Rui, Gita e da narradora de Caderno de memórias coloniais. Tal como o pai não ficcional de André, os pais dos narradores dos romances passam por muitas dificuldades econômicas em Portugal e veem na ida para a África uma oportunidade de melhorar as condições da família. A partida de Angola, para os pais de André, é tão custosa quanto a partida para os pais de Rui e da narradora de Caderno. O que resta de material dessa vida, então, é o que cabe em um contentor. No entanto, a partida física imposta da África não significa a partida afetiva, como ocorre com o pai de André e com as personagens dos romances analisados, de modo a suscitar a problematização da permanência do tempo passado. 
O fim da narrativa de Cardoso é preponderante para a marca da permanência do passado:

Um avião risca o céu a direito. Silencioso. Como um giz preguiçoso nas mãos invisíveis de deus. Noutro tempo ter-Ihe-ia respondido daqui de baixo. Talvez ainda responda. Noutro tempo ter-Ihe-ia escrito, talvez ainda escreva, em letras bem grandes a todo o comprimento do terraço para que não possa deixar de ver-me, eu estive aqui.

Eu estive aqui. (CARDOSO, 2012, p. 267)

O contexto do excerto diz respeito ao dia em que Rui e a família vão finalmente deixar o hotel, de onde desejavam sair desde o dia da chegada. "Noutro tempo" refere-se a um tempo passado, um tempo de maiores certezas. É nesse tempo que Rui localiza também uma certeza de resposta, mas ainda no presente da narração a resposta é cogitada. A resposta escrita no chão, em letras grandes, inviabiliza o esquecimento, apesar da tentativa de imposição de um silêncio por parte da sociedade portuguesa. Escrever sua existência é também inscrever sua memória.

Se no caso de Rui há a escrita e a inscrição de si no chão do terraço do hotel, Gita, narradora de $A$ árvore das palavras, lembra-se de um momento de sua adolescência que evidencia a relação entre escrita e memória firmadas em um tempo: 
Foi quando decidimos escrever a frase a carvão, na parte de fora do muro do liceu. Para que não esquecessem. Porque a guerra era longe e a vida na cidade continuava igual, como se nada fosse.

[...]

Roberto escreveria "Viva Moçambique", e a mim caberia escrever "Independente". Com um ponto de exclamação a seguir.

Exactamente no momento de cortar o $\mathrm{T}$ viram-se faróis no fim da rua. Acabei como pude o que faltava e escondi-me atrás da árvore mais próxima. (GERSÃO, 2004, p. 184)

A própria narradora vê na escrita a capacidade de reter a lembrança. Como parecia não haver guerra na cidade, Gita percebe a importância de fazer lembrar o conflito e o motivo de sua existência, a independência do país. A escrita se configura, também nesse caso, não só a afirmação da própria identidade, mas também a inscrição histórica de um tempo, em que viveu e lutou contra o colonialismo. É interessante pensar que a ela fica a responsabilidade de escrever a palavra "independente" e um ponto de exclamação. Tal como o país, a adolescente Gita também precisa lutar por sua independência, da família, da lógica colonial, e, por isso, parte para Portugal.

A lembrança sobre a confecção de um cartaz também em defesa da independência de Moçambique, para colar na porta da escola, permite pensar, da mesma forma, na inscrição de si em um tempo. Sobre esse momento, Gita recorda: 
Ela crescia nos sonhos, digo a Roberto enquanto pintamos o cartaz. A árvore das palavras. Para contornar o seu tronco seriam precisas nove luas. E cada folha era extensa como um voo de pássaro.

Mas de certeza que não só nos meus sonhos: Crescia também nos de toda a gente. (GERSÃO, 2004, p. 170)

A árvore, elemento tão importante nas culturas africanas, é mencionada diversas vezes ao longo da narrativa. Como um elemento que perpassa diferentes gerações, de modo a resistir aos efeitos do tempo, é ela responsável por conectar antepassados aos familiares que ainda estão vivos. Em alguma medida, é guardiã de uma memória que não se deseja esquecer. No excerto no romance, se a árvore é das palavras, novamente se associa a palavra à memória. É a palavra que não se quer perder e por isso fazer brotar e durar por meio da árvore. Desse modo, o crescer da árvore nos sonhos, ao mesmo tempo da feitura do cartaz e da guerra pela independência, sugere o crescer de um posicionamento crítico acerca do presente ancorado na lembrança do passado, a inscrição de uma palavra-memória própria.

As narrativas literárias de infâncias e adolescências, em nada idealizadas nessas obras literárias, desmistificam as narrativas unificadoras da nação, que evidenciam um tempo homogêneo e, portanto, também uma memória 
homogênea. Nos romances de Figueiredo, Cardoso e Gersão, a memória dos protagonistas assinala a hipocrisia de um discurso nacionalista que enaltece o português, mas o trata como "cidadão de segunda" caso tenha nascido e/ou vivido nas colônias africanas. São essas memórias, desse modo, da ordem das "contranarrativas" (BHABHA, 2013), subterrâneas (POLLAK, 1989) e contra-hegemônicas (GRAMSCI, 1982), pois contribuem para rasurar fronteiras e questionar legitimidades muitas vezes aceitas no universo adulto.

Desse modo, ao mesmo tempo em que há nessas narrativas a apresentação de lembranças de sensibilização para com o outro propiciada por uma ignorância mobilizadora, há também lembranças de uma condição de desassossego, de inquietude, necessária para não se acomodar diante da vida (KOHAN, 2015). Devido ao fato de esses sujeitos estarem ainda em uma condição mais solitária, menos disciplinada em relação ao mundo (FOUCAULT, 2004), essa sensibilidade e vontade de subversão são possíveis.

Afetar-se e afetar o outro são ações que os narradores em questão exercem, seja esse outro personagem, seja o leitor. Esses narradores, tendo seus discursos postos em xeque por uma ordenação social que privilegia modos de pensar pela perspectiva do adulto, que representaria a tão valorizada 
ideia de razão, não são colocados no outro extremo do discurso, o da revelação de uma verdade absoluta, como ocorre com o louco, conforme salienta Foucault (1996). São, sim, apresentados em complexidade, com contradições, questionamentos, angústias, compreensões sobre o mundo que diferem em alguns pontos das do adulto e por isso permitem seu questionamento. Infâncias e adolescências são então potências do narrar, exercendo uma seleção de prioridades que possibilita o questionamento ao leitor, rasurando as narrativas de coesão tão difundidas acerca do colonialismo português na África.

\section{Referências}

BHABHA, Homi. O local da cultura. Tradução de Myriam Ávila, Eliana Lourenço de Lima Reis e Gláucia Renate Gonçalves. Belo Horizonte: Editora da UFMG, 2013.

CHICO, Buarque de Hollanda. A banda. In: Chico Buarque de Hollanda. São Paulo: RGE, 1966. 1 disco sonoro, faixa 1 (2 min $11 \mathrm{seg}$ ).

CARDOSO, Dulce Maria. O retorno. Rio de Janeiro: Tinta-da-china Brasil, 2012. FIGUEIREDO, Isabela. Caderno de memórias coloniais. Alfagride: Editorial Caminho, 2015. [E-book].

FOUCAULT, Michel. A ordem do discurso. Tradução de Laura Fraga de Almeida Sampaio. São Paulo: Edições Loyola, 1996.

FOUCAULT, Michel. Vigiar e punir - Nascimento da prisão. Tradução de Raquel Ramalhete. Rio de Janeiro: Vozes, 2004. GERSÃO, Teolinda. A árvore das palavras. São Paulo: Editora Planeta do Brasil, 2004.

GOMES, Catarina. Pai, tiveste medo? Lisboa: Matéria-Prima Edições, 2014. 
GRAMSCI, Antonio. Os intelectuais e a organização da cultura. Tradução de Carlos Nelson Coutinho. Rio de Janeiro: Editora Civilização Brasileira, 1982. HALBWACHS, Maurice. A memória coletiva. Tradução de Beatriz Sidou. São Paulo: Centauro, 2003.

KILOMBA, Grada. Memórias da plantação: episódios de racismo cotidiano. Tradução de Jess Oliveira. Rio de Janeiro: Cobogó, 2019. KOHAN, Walter Omar. Visões de filosofia: infância. ALEA, Rio de Janeiro, v. 17/2, p. 216-226, 2015.

MASSEY, Doreen. Pelo espaço: uma nova política da espacialidade. Tradução de Hilda Pareto Maciel e Rogério Haesbaert. Rio de Janeiro: Bertrand Brasil, 2008.

MELO, Vanessa de Pacheco. Urbanismo português na cidade de Maputo: passado, presente e futuro. Revista Brasileira de Gestão Urbana. Curitiba, v. 5, n. 1, p. 71-88, janeiro/junho de 2013. MEMMI, Albert. Retrato do colonizado precedido de Retrato do colonizador. Tradução de Marcelo Jacques de Moraes. Rio de Janeiro: Civilização Brasileira, 2007.

POLLAK, Michael. Memória e identidade social. Estudos históricos. Tradução de Monique Augras. Rio de Janeiro, v. 5, n. 10, p. 200-212, 1992. POLLAK, Michael. Memória, esquecimento e silêncio. Estudos históricos. Tradução de Dora Rocha Flaksman. Rio de Janeiro, v. 2, n. 3, p. 3-15, 1989. RIBEIRO, Margarida Calafate. Itinerâncias: percursos e representações da pós-colonialidade. Porto: Edições Húmus, 2012.

SANTOS, Boaventura de Sousa. Boaventura: o colonialismo e o século XXI. Outras palavras - jornalismo de profundidade e pós-capitalismo, 15 jan. 2019. Disponível em: https://outraspalavras.net/geopoliticaeguerra/ boaventura-o-colonialismo-e-o-seculo-xxi/. Acesso em: 20 set. 2019.

ZAMPARONI, Valdemir Donizette. Entre Narros \& Mulungos: colonialismo e paisagem social em Lourenço Marques c. 1890 - c.1940. 1998. Tese (Doutorado em História Social) - Faculdade de Filosofia, Letras e Ciências Humanas da Universidade de São Paulo, São Paulo, 1998. 


\section{Cristina Arena Forli}

Doutoranda em Estudos de Literatura no Programa de Pós-Graduação em Letras da Universidade Federal do Rio Grande do Sul, sob orientação da Profa. Dra. Jane Fraga Tutikian.

E-mail: crisforli@gmail.com

Lattes: https://lattes.cnpq.br/3528525794109781

ORCID: https://orcid.org/0000-0002-9750-6408 